Journal of Agrarian Change, Vol. •• No. ••, •• 2016, pp. ••-••.

\title{
Fragmented Territories: Incomplete Enclosures and Agrarian Change on the Agricultural Frontier of Samlaut District, North-West Cambodia
}

\author{
JEAN-CHRISTOPHE DIEPART AND THOL SEM
}

In Cambodia, the interactions between large-scale land investment and land titling gathered particular momentum in 2012-13, when the government initiated an unprecedented upland land titling programme in an attempt to address land tenure insecurity where large-scale land investment overlaps with land appropriated by peasants. This paper is based on a spatially explicit ethnography of land rights conducted in the Samlaut district of north-west Cambodia - a former Khmer Rouge resistance stronghold - in a context where the enclosures are both incomplete and entangled with post-war, socially embedded land tenure systems. We discuss how this new pattern of fragmentation affects the prevailing dynamics of agrarian change. We argue that it has introduced new forms of exclusion and a generalized perception of land tenure uncertainty that is managed by peasants through the actualization of hybrid land tenure arrangements borrowing from state rules and local consensus. In contrast with common expectations about land formalization, the process reinforces the patterns of social differentiation initiated by land rent capture practices of early migrants and pushes more vulnerable peasants into seeking wage labour and resorting to job migration.

Keywords: territorialization, enclosures, social differentiation, Khmer Rouge, Cambodia

\section{INTRODUCTION}

Large-scale land investments that come under the rubric of 'land grabs' are occurring to a significant extent and at a substantial pace in South-East Asia (Borras and Franco 2011), including Cambodia (LICADHO 2014). They are becoming increasingly connected to land titling initiatives partly due to the growing spatial overlap but also to the political economic convergence of both processes (Diepart 2015; Dwyer 2015). Land (in)security lies at the core of this intersection; titling is seen as a tool to provide smallholder farmers with security of tenure that would protect them from dispossession by 'land grabs'.

The importance of securing peasant land rights in the context of large-, medium- or small-scale investment in farmland is strongly echoed in several international guidelines calling for more responsibility in large-scale agricultural investments (e.g. FAO, 2012).

Jean-Christophe Diepart, Scientific Collaborator, Gembloux Agro-Bio Tech, University of Liège, Belgium. Contact address: \#652, Chrey Kaong village, Battambang Municipality, Cambodia. E-mail: jc.diepart@gmail.com. Thol Sem, Independent researcher, Pailin, Cambodia. E-mail: semthol@gmail.com

This paper results from a partnership between AgroParisTech (UFR Agriculture comparée et développement agricole/UMR Prodig), the association AGTER and the authors. It is part of a research project supported by the Agence Française de Développement (AFD) through the Technical Committee on 'Land Tenure and Development'. We are grateful to AFD for financial support and to the scientific support provided by AgroParisTech (Olivier Ducourtieux and Hubert Cochet) and AGTER (Mathieu Perdriault and Michel Merlet). Thanks go to John Pilgrim and Jeremy Ironside, who both made insightful observations on a first draft. We are very grateful to the Journal associate editor and the anonymous referees who made detailed and very constructive comments. All remaining errors are ours. 
From an agrarian justice perspective, it seems essential to provide smallholder farmers with land tenure security, particularly in countries with a large peasant population like Cambodia. However, the effect of titling on controlling large-scale land grabs does not necessarily conform to idealistic expectations. Land titling and the development of a market for land property rights is considered by many observers as unaffordable for cash-strapped farmers and is associated historically with the capture of the process by the local elites (De Schutter, 2011; So, 2009). Other authors emphasize the negative effect of titling: that it inevitably results in the absence of land titling in certain areas, which weakens security and reinforces inequalities in land access (Hirsch, 2011; Milne, 2013).

In Cambodia the interactions between land grabs (large-scale land investment exemplified by socalled economic land concessions (ELCs), or through illicit land acquisition by powerful figures such as military officers) and land titling gathered momentum in 2012-2013 when the government initiated an unprecedented upland land titling programme called Order 01 (Royal Government of Cambodia, 2012). This was an attempt to tackle conflict situations in which agro-industrial ELCs overlap with landholdings of traditional land users and migrant peasants (Diepart, 2015; Müller and Zülsdorf, 2013).

How the intersection between ELCs and land titling re-shapes land tenure security and transforms land-based social relations and the actual development of agrarian systems, is the subject of this contribution. We are particularly interested in looking at areas where both processes are only partially implemented on the ground, either due to incomplete titling efforts or to incomplete implementation of agro-industrial operations on the concession land. This situation of incompleteness actually prevails across Cambodia and is not sufficiently addressed in current 'land grab' debates.

Our organizing proposition is that the entanglement of locally embedded tenure regimes, i.e. post-war land appropriation under Khmer Rouge control, with incomplete large-scale state land concessions and incomplete titling, lead to new forms of fragmentation in rural territories, with the nature of land tenure [in]security distinct within each 'fragment'. These transformations create spatially-differentiated land property dynamics that reshape pre-existing patterns of agrarian change. We argue that the incomplete nature of the private and state enclosures results in a widespread uncertainty in land tenure and further suggest that territorial fragmentation reinforces the pre-existing patterns of social differentiation. It formalizes the upfront land rent capture process operated by early migrants in the post-war land pioneer process and truncates the upward mobility of the others. Down the line, these transformations exacerbate the mobility of labour through wage and job-migration.

The paper proceeds as follows: we first briefly present the context of recent land formalization processes in Cambodia and the fragmentation propelled by the intersection between large-scale land concessions and titling in Cambodia. We then conceptually frame the study at the intersection of land control and agrarian change by drawing on the notions of territorialization, land tenure security and social differentiation. Third, we present our methods and the case study we have investigated. Four, we present how the recent incomplete enclosure processes have intersected with post-war land distribution by the Khmer Rouge to produce the territorial fragmentation. Fifth, we show the relations between the plurality of institutional arrangements and the security of land tenure. Sixth, we then discuss how they affect pre-existing patterns of social differentiation and outline their effects in relation to agrarian change.

\section{THE CONTEXT OF RECENT LAND RIGHTS FORMALIZATION IN CAMBODIA}

In addition to establishing a moratorium on ELCs, Order 01 aims to tackle widespread conflicts resulting from apparent overlaps between land possessed by peasants and land earmarked for economic concessions. Land insecurity is tackled by granting farmers private property land titles where they cultivate, a process Dwyer (2015) calls the 'formalization fix'.

ELC lands are spatially very significant, covering over 2.1 million hectares in the uplands (LICADHO, 2014). The extensive disputes relating to these ELC lands resulted from a lack of recognition of traditional land use rights and the absence of coordination between the attribution of ELCs and massive 
lowland-to-upland migration and associated land appropriation ${ }^{1}$. This has accelerated over the last 15 years as a response to growing problems in terms of land access and poverty in the central low-land rice plain (Diepart, Pilgrim, and Dulioust, 2014). These migratory movements are best understood in relation to historically rooted practice - commonly known as appropriation "by the plough" - that legitimizes land access by clearance and cultivation. As long as it does not infringe on the rights of others in the community, the cultivation of a piece of land for subsistence farming provides farmers with individual possession rights (paukeas in Khmer), which allow for use, harvest and exclusions. In this context, land tenure security predominantly works through recognition of possession rights legitimized by local authorities through local institutions (Olivier, 1954). However, the 2001 Land Law restricts legal possession to land occupied before 2001. This has resulted in a huge population living on land that they appropriated after 2001 in respect of which they have virtually no land tenure security under the 2001 Land Law institutions (Diepart, 2015).

There was an electoral objective behind Order 01 as the government seized the opportunity to calm the social unrest in the perspective of the then-imminent local and general elections. However, exclusion and violence deployed prior to and during the titling process have been widely reported (Beban and Work, 2016 - forthcoming; Grimsditch and Schoenberger, 2015).

The titling process that follows the so-called 'leopard skin' strategies under Order 01 foresees that plots cultivated by people prior to the granting of the ELCs are to be excised from the concession through titling, leaving the concession land spotted like a leopard skin. It has been presented by the government as a further step in the land reform to resolve and legalize unclear land occupation by users on state land (Im, 2012), suggesting that large-scale concessions can co-exist with the pre-existing land use arrangements.

\section{A CONCEPTUAL APPROACH TO TERRITORIAL FRAGMENTATION}

The object studied in this contribution is the territory that we embed historically following the work of Elden (2010) who envisages it as an intertwined set of political economic, strategic and technologic issues. Territory, he argues, includes questions of access, distribution, property and competition (the political economic), questions of control and power in the enforcement of authority (the political strategic) but also questions of techniques for measuring land which are embedded in a legal apparatus (the political technologic).

We propose to outline a conceptual framework that allows a better understanding of territorial fragmentation linking the dynamics of land control and agrarian change. We envisage processes of land control after Peluso and Lund (2011) as 'strategies and practices that aim to fix, consolidate and legitimize access to land and its resources' and pay particular attention to processes of territorialization.

In a nutshell, our analytical approach leads us to first elicit patterns of central state territorialization at play through the imposition of land titling and land concessions that we conceptualize as [incomplete] enclosures. We then explore the institutional pluralism resulting from the overlap between these [incomplete] enclosures and local land tenure systems characterized by post-conflict control over land distribution and agrarian expansion by ex-Khmer Rouge local authorities. Last, we examine how these multi-layered patterns of land control affect the dynamics of social differentiation between peasants.

${ }^{1}$ We refer to land appropriation in a widely accepted sense as a process through which peasants access, use and acquire exclusive benefit from a piece of land. It comprises a plurality of access such as inheritance, gifts, donations, land distribution, land clearing, purchase, etc. The notion of land appropriation incorporates a transfer of rights on the land. The word 'rights' is conceived here in social terms - an action over a resource that is seen as socially legitimate - rather than in legal terms (Pel et al., 2008). 
We envisage land concession and land titling as instruments of state-driven land control that is being created through processes of territorialization, a term we use after Sack (1986) as 'the attempt by an individual or group to affect, influence, or control people, phenomena, and relationships, by delimiting and asserting control over a geographic area'.

In its exercise of territorialization, the state uses titling and concession as enclosures to facilitate the transformation of agrarian structure. These enclosures suppose a specific mode of land right formalization that is an essential element in the process of capitalist commodification of land and natural resources. Castree (2003) suggests that this is a dynamic process that physically delineates a fragment of land and associated resources (material boundary) and legally extracts it from its context (legal boundary). But as Akram-Lodhi posits, enclosure is about more than just land. It is also a pathway to 'deepen capitalist social property relations by diminishing the relative power of peasants and workers in favour of dominant classes' (AkramLodhi, 2007).

With titling, the state disciplines the management of territories; it demarcates, identifies what belongs to people and to the state and controls land use patterns (Biddulph, 2010; Scott, 1998). Land titling is the final stage in the individualization of private land property rights. It is a process of land right alienation supposed to bring land tenure security, raise land value, collateralize land for the uptake of credit and productivity improvement (de Soto, 2000) and can be the foundational step towards the development of a land property rights market supposed to allocate land between farmers in an effective and pro-poor way (Deininger, 2003). For more than a decade, however, there has been a growing set of critiques arguing that in the global south, and in Cambodia in particular, land titling has not met these expectations. It has not mechanically increased the security of tenure (Land Tenure and Development Technical Committee, 2015; So, 2009), it is associated with the capture of the process by local elites (De Schutter, 2011; Grimsditch, Kol, and Depika, 2012) and has not necessarily resulted in any gain in land productivity (Biddulph, 2010; Chimhowu and Woodhouse, 2006). Additionally, the development of a land market opens the possibility of distress-sales by the poor in times of hardship, thus accelerating social differentiation (Chimhowu and Woodhouse, 2006) and landlessness among the poor (Chan, Tep, and Acharya, 2001).

In turn, large-scale land concessions have been instrumental in enabling the state to [re] exert control over peripheral areas and peoples (Wolford, Borras, Hall, Scoones, and White, 2013). In Cambodia, state land enclosure has been an important source of revenue to support warfare and post-war state building (Hibou, 2004; Le Billon, 2000) and also, from the end of the nineties onwards, to enable the consolidation of the ruling-party's power (Un and So, 2011). Large-scale land investment can be envisaged in a broad perspective as a public-private partnership between a state authority and an agro-industrial corporation for the purchase or lease of a designated area of land (Land Tenure and Development Technical Committee, 2010). Those who promote such land investment, usually emphasize the opportunity it offers to use investor interest and resources in ways that can increase smallholder productivity and improve local livelihoods. The premise is that so-called underutilized or vacant/idle land is consequently subjected to an effective and efficient production scheme through which smallholders, or out-growers, can benefit through various forms of contractual arrangements (Deininger et al., 2011). But in Cambodia, and elsewhere, large-scale land acquisitions are notorious for reshaping rural contexts in ways that lead to varying degrees of land dispossession for small-scale farmers and exacerbate the recourse to wage labour that does not usually compensate for the loss of resources that local people depend on (Gironde, Golay, Messerli, Peeters, and Schönweger, 2014).

We suggest that both enclosures - large-scale land investment and land titling - are actually incomplete in time and space, a trait that adds complexities to the debate about land tenure security. First, the default of titling in certain areas reassigns untitled land as state property, which might further exacerbate risks of land grabs (Hirsch, 2011; Milne, 2013). Yet areas that have been excluded from titling are significant because the titling programme had to be conducted over a very short period with visible output, leaving sub- 
national authorities with a dilemma in deciding which areas should be included in the adjudication. Second, as White et al. (2012) suggest, large-scale land deals are often no more than an initial framework, which might, or might not, materialize in production and effective enclosure with dispossession of its previous users in a different time frame. Actually, this situation of incompleteness in concession operation, which prevails in most of Cambodia (Sperfeldt, Tek, and Chia-Lung Tai, 2012), is due partly to the highly speculative nature of these land deals, and partly to the fact that ELCs are often a tactic to circumvent the 2002 ban on logging: their clandestine aim is more to engage in timber logging than to conduct the agro-industrial activities specified in the agreement (Global Witness, 2007; Hibou, 2004; Milne, 2015).

The incomplete nature of both types of enclosure obliges us to envisage a multiplicity of contexts of fragmentation according to the actual use, titling or implementation of the ELC. This zoning creates visible or invisible systemic edges in the territory - sensu Saskia Sassen (2014) - as they differentiate fragments of territory where the relations between peasants, their bio-physical and institutional milieu are distinct. The temporal dimension is also important in the territorial fragmentation, as the actual enclosure process is rather gradual on the ground with varying impacts on local livelihoods.

\section{Post-Conflict Territorialization and Institutional Pluralism in Land Tenure}

The enclosure process disembeds land from its bio-physical, cultural, social and institutional context - sensu Polanyi (1957) - and overwrites complex and multi-shaped land-based social relations and variegated forms in the management of land resources (Borras and Franco, 2012; De Schutter, 2011; Springer, 2013). The socially embedded institutions for land tenure in this region of Cambodia are shaped by post-conflict land control operated by old Khmer Rouge warlords through territorialization, a process that has triggered considerable in-migration and shaped the opening of the agricultural frontier. Diepart and Dupuis (2014) have argued that the tensions between Khmer Rouge and neoliberal modes of land control are central to contemporary territorial and state formation processes along the agricultural frontier in Northwest Cambodia.

In a context of institutional pluralism, several competing claims, norms and legitimacy over land control and security of tenure are at play; the state-licensed formalization of land rights oriented towards the marketability of land and inalienable private property rights, and the local arrangements securing individual entitlements under local social rules and consensus under ex-warlords. Conceptually, we do not envisage these different forms of legitimacy over land as simply complementary but rather co-existent so that a single situation could be subject to, or be confronted by, more than one legal order or institutional mechanism (Merry, 1988; von Benda-Beckmann, 2002). However, as Pel et al. (2008) have argued, each set of norms is subject to its own internal contradictions, particularly in the context of Cambodian neo-patrimonial practises that empower and legitimize officials at various levels to authorize transactions over land under their jurisdiction.

Institutional pluralism resulting from multi-layered patterns of territorialization engages state authorities (from national to local level) in different forms of relations with each other and with peasants. These relations are established between people in their attempts to secure their rights to land and a politicolegal authority that can recognize their claim as legitimate. As Sikor and Lund have argued, a dialectic lies at the core of these relations. The process of supporting or complying with norms and rules regarding the allocation of land works to legitimize those with the authority to implement the rules (Sikor and Lund, 2009). In contrast, the process of evading or resisting these rules tends to discredit and weaken those with the authority to implement them.

\section{Land Control and Social Differentiation}

A central tenet of the study is to examine how multi-layered territorialization, mediated by a plurality of land tenure arrangements, affects the pre-existing patterns of agrarian change, which we envisage through social 
differentiation. We approach social differentiation following Bernstein (2010) as the transformation of social relations of production between peasants, and with it, the differentiation of their capacity to reproduce their means of production and possibly accumulate assets and wealth.

The social relations that structure production are a function of two mechanisms (Akram-Lodhi, 2005) that are shaped, at least partly, by the inclusions or the exclusions in land access resulting from territorialization processes. The first is the process of differentiation in [land] asset endowment, which works through market and non-market mechanisms between those with relatively larger and those with relatively limited quantities of productive assets. The second, which is contingent upon the differentiated control of productive assets, is the capacity to generate and control technical change and capture benefits from increased asset productivity.

Social differentiation is usually indicated by the polarization of, at the one end, a labour-selling class of agrarian proletarians (or semi-proletarians), and at the other, an entrepreneurial labour-buying agrarian class (Akram-Lodhi, 2007; Bernstein, 2010). Hall et al. (2011) describe these processes as 'intimate exclusions' to underline the fact that they are at play form below between social intimates. These authors suggest that agrarian differentiation merits particular attention in the context of frontier areas where it is increasingly difficult for people who lose land through processes of exclusion in one location to move off and try in another.

\section{RESEARCH METHODS}

We illustrate these processes of territorial fragmentation on the basis of a case study conducted in Samlaut district (in Northwest Cambodia), specifically in and around the Rath Sambath rubber concession approved by the government in 2009 (Open Development Cambodia, 2014), with a specific focus on the villages of Chhak Rokar, Chamkar Chek and Ou Ta Trek. Chhak Rokar and Chamkar Chek are neighbouring villages located to the north of the rubber concession in a similar agro-ecological zone, but are separated by the titling efforts. Ou Ta Teak land is intertwined with concession land in the east and is located in an agro-ecological context that is very different to that of the other two villages (see Figure 1).

This area was chosen because it complements previous research conducted in the neighbouring district where agrarian expansion occurs without the intervention of an economic land concession. The field research uses a variety of methods. We first historically contextualize the research site by reviewing a fund of literature and press reports that monitor this region of Cambodia. Indeed, it is significant as the source of a peasant uprising in 1967 and as the focus of Khmer Rouge resistance until the end of the nineties. We conducted a number of in-depth interviews $(n=5)$ with land administration officials at national, provincial and district level who had been involved in the Order 01 land titling and/or who were familiar with the Rath Sambath concession. We also conducted interviews with two representatives from conservation NGOs active in the area. We developed a geo-reference database that was instrumental in performing a preliminary spatial analysis of land use and land tenure dynamics. 
Figure 1. Study area

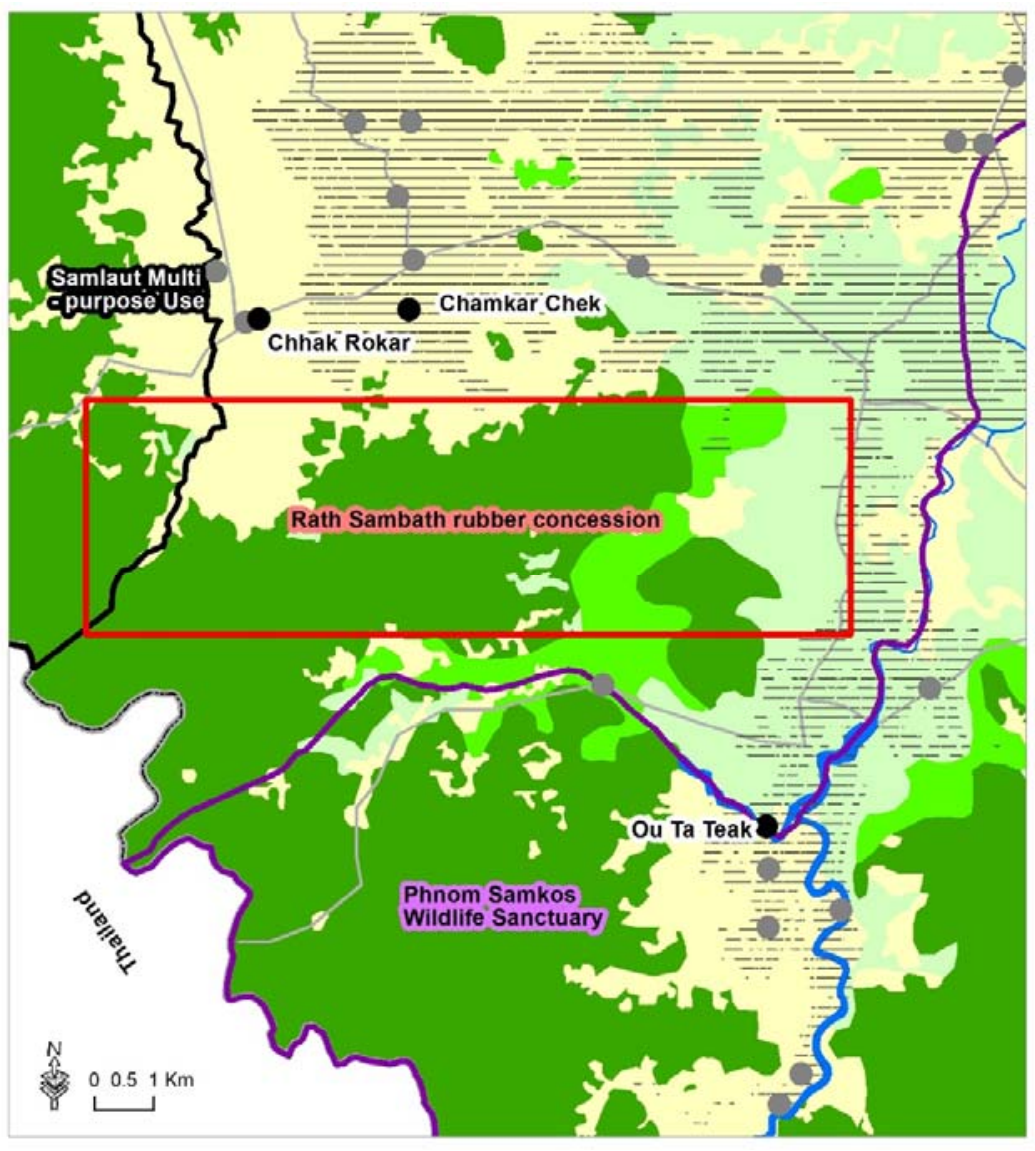

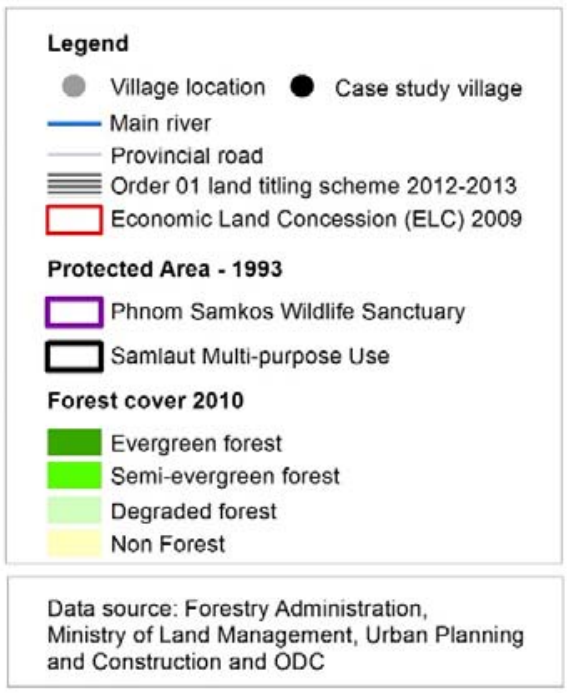

and Construction and ODC

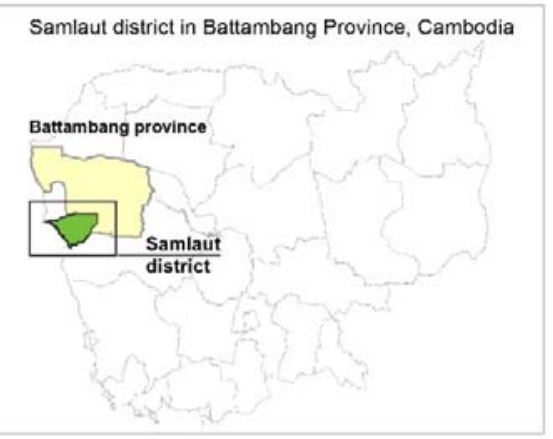

This preliminary analysis was discussed with commune authorities $(n=3)$ with the aim of identifying villages for field investigations. In this exercise, we wanted to choose villages that represented the diversity of intersections between land tenure regimes in and around the Rath Sambath ELC. Three villages with contrasting regimes were eventually selected (Figure 1). We then conducted short interviews with village leaders.

During field work an ethnography of land rights was structured by three different types of discussions. First, in each village we conducted a focus group discussion with peasants - usually elders - who were knowledgeable about land distribution and appropriation from the early days of the village (after 1979) until now. We facilitated the mapping of land distribution and land appropriation and used the map as a basis to discuss issues of land security that had emerged before and after the implementation of the ELC and Order 01 titling. We also conducted a household wealth ranking exercise to identify trends in socio-economic differentiation in the village. This exercise served to identify a diversity of families with distinct farming systems for in-depth interviews that we conducted in the three different villages $(n=40)$ to elicit a fine-grained understanding about household trajectories, farm production decision-making mechanisms, the creation of value-added, dependence on credit, and family labour management including national and international labour migration. In addition, we conducted many unsolicited interviews with people whom we met incidentally during fieldwork (farmers, traders, middlemen, and representatives from village authorities). All field-based discussions and interviews were conducted in Khmer by the researchers in June and July 2014. 


\section{THE PRODUCTION OF FRAGMENTED TERRITORIES}

After the demise of Democratic Kampuchea in $1979^{2}$, the Northwest region - the Samlaut district in particular - became the base for some Khmer Rouge (KR) resistance against government and Vietnamese forces, which resulted in violent conflicts that lasted until the late nineties. In 1996, a reintegration policy was initiated with the aim of providing KR warlords with the power to plan and supervise the distribution of land in this region to demobilized soldiers and in-migrant peasants (Gottesman, 2003). Land distribution and associated migration have opened the agricultural frontier and the emerging social order has crystalized processes of land control by old KR warlords (Diepart and Dupuis, 2014).

The recourse to enclosures for land management and territorial development is embedded in this historical context of violence. And when they are coupled with the threat of force, initially employed by the military for territorial acquisition and control in warfare and later by agricultural entrepreneurs colluding with state bureaucracy actors, these enclosures have become institutionally deviant in the sense that force is legitimized by government institutions against private citizens and interests (Pilgrim, Ngin, and Diepart 2012).

\section{Land Appropriation in Chhak Rokar and Chamkar Chek}

A first phase of land distribution took place in the chaos of the early eighties that followed the escape of members of the Khmer Rouge to a resistance base in the Northwest. In this region that remained under KR control, the rule was to distribute five hectares of forested land to each family, who could later clear and convert it to agricultural land. This early land distribution remained effective on the ground; people never lost access to the land they were allocated at that stage, even if, subsequently, the rampant conflict obliged them to move to safer locations.

In Chhak Rokar and Chamkar Chek, the first group of migrants were closely related to the local KR military unit (angkapheap) who controlled the land distribution. They were a mix of not-yet-demobilized KR soldiers and people who had lived in the area before the war. The appropriation of better quality land in the village (better soil fertility and access to water) followed a logic of 'first come, first served' and thus these early migrants were at an advantage. These areas now constitute the central area of the village where main roads have been developed giving better access to market. This central area also offers better public infrastructure and forms a main transportation axis to the Thai border (Figure 1). The peasants who subsequently migrated to this area were usually related to the earlier migrants through family or acquaintance networks. They settled in the village and received land according to the same distribution rules but in areas increasingly located at the periphery of earlier settler landholdings (Figure 2). In addition to being located further from village centres and infrastructure, land appropriated by these subsequent migrants was of worse quality (more rocky, shallow and sandy soils). From 2001, appropriation of land was even conducted through sale, which also allowed rich outsiders to acquire large landholdings in the villages.

The agrarian developments first expanded southward, largely inside what constitutes the present day Rath Sambat rubber concession (Figure 2), and then westwards inside the Samlaut Multiple Use Protected Area. Although this was established in 1993 it was not, at that early stage, under the effective control of officers from the Ministry of Environment who were theoretically charged with managing this initiative.

Given the considerable tracts of land suitable for cultivation within this study area, the opening of the agricultural frontier has created incentives for migration as transforming forest to agricultural land is a very labour-demanding dynamic. However, all the peasants accepted the relationship between the local authority and the land access rules imposed by the Khmer Rouge elite; those were the rules of the game and none of

\footnotetext{
${ }^{2}$ The name given to the country under the Khmer Rouge regime 1975-1979
} 
our respondents said that these rules were contested. Land security was socially built within the relational process of land attribution and appropriation in a way that legitimated the land authority.

Figure 2. Land appropriation and enclosures in and around the Rath Sambath rubber concession. Note: The numbers indicate the different fragments of territory that are described later in figure 3.

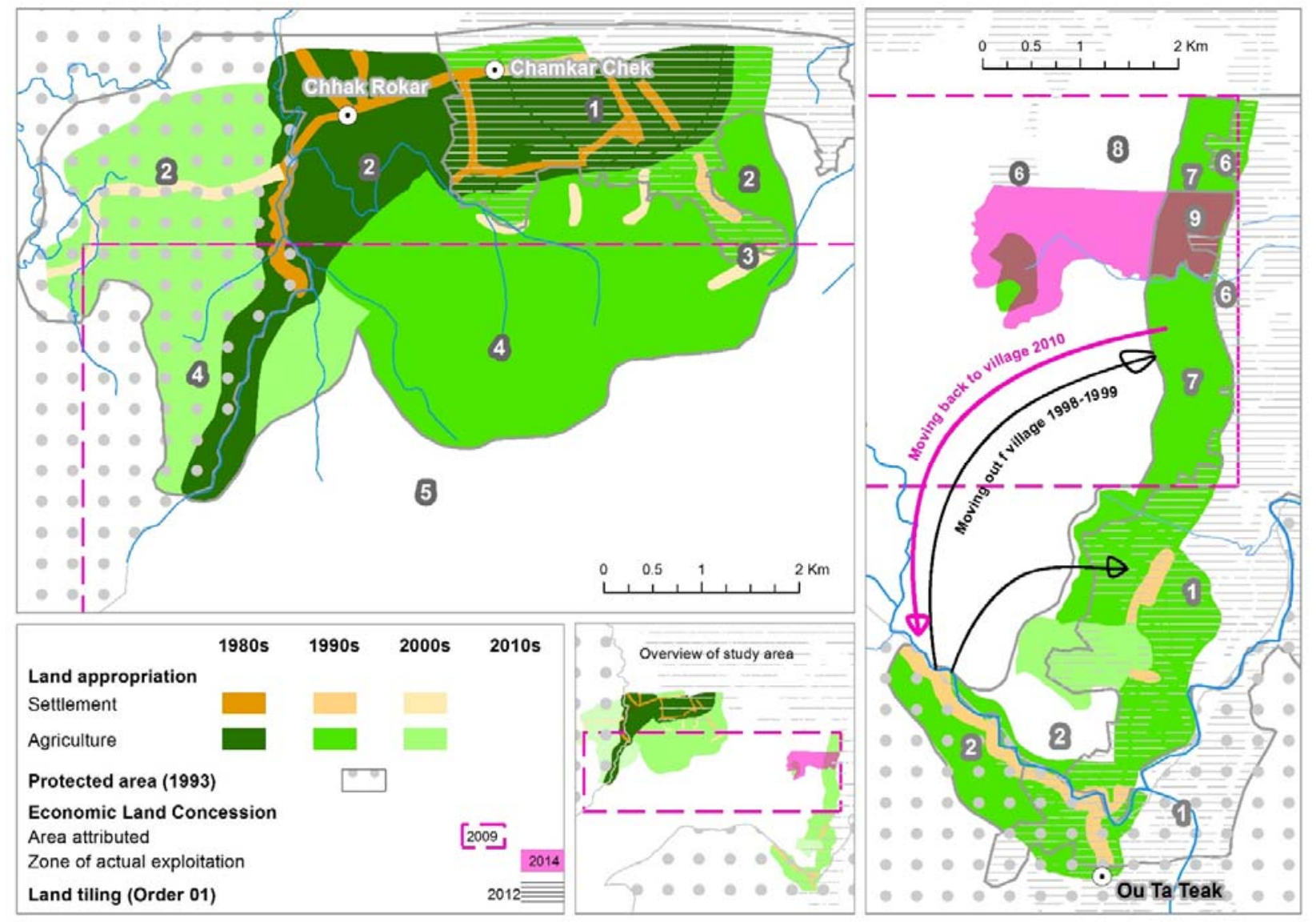

\section{Land Appropriation in Ou Ta Teak}

Ou Ta Teak village is located in another corner of the present-day Rath Sambath rubber concession (Figure 2). We separated it from the other two village as it differs significantly in terms of agro-ecology, land appropriation and enclosures. In this village, the initial land distribution was also implemented under the control of a local military unit (Angkapheap) in the early nineties, when Khmer and ethnic minority groups (Por, Jarai, and Kouy) came back from the refugee camps on the Thai border. The agricultural land located in the central area of the village was the first to be distributed, followed by the land in the surrounding hills. But the process was particularly complicated due to the massive presence of unexploded mines.

A similar process of upfront land capture by the local elite has taken place that has allowed them to appropriate land that has the best access to water. The Por indigenous people moved back to the ground they had traditionally used for swidden agriculture, but which they had abandoned during the war. It is interesting to note that the Khmer people mimicked their indigenous neighbours by engaging in swidden agriculture in the surroundings hills. This land on the hill was distributed by the Angkapheap in plots of approximately 0.75 to 1 ha in total area size depending on the labour capacity of the family. In 1993, the establishment of Phnom Samkos Wildlife Sanctuary (another Protected Area) considerably limited the expansion of swidden despite the continuing arrival of migrants seeking land suitable for swidden agriculture. To anticipate the land needs of generations to come, local authorities in Ou Ta Teak, in concert with authorities of other villages in Ta 
Taok commune, decided in 1993 to allocate land located further north in a 700 meter-wide strip of land that follows a road in development (Figure 2). This is located inside the present-day Rath Sambath rubber concession. The land was attributed to families (1.4 ha per household) who could keep it in reserve until they were ready to cultivate. Around the years 1998 to 1999, some families were able to materialize their claims on those reserved lands (Figure 2). The operations had to start with an expansive demining campaign that peasants undertook themselves or by paying for private specialized services. Due to the absence of basic infrastructure in these new locations, nearly all peasants focused land activity - and had their main residence - in the old village, and only established a secondary shelter in these new locations.

\section{Rath Sambat Rubber Concession: the Making of an Incomplete Enclosure}

When the Rath Sambath rubber concession was assigned in 2009 to a company represented by a wellconnected Cambodian lady from Phnom Penh, the objective of the 70-year deal was to establish a rubber plantation on an area size of 5,200 ha. The land deal was established through sub-decree (Royal Government of Cambodia, 2009) the day immediately after a request was sent to the Prime Minister by the Minister of Agriculture, Forestry and Fisheries (MAFF, 2009). As indicated above, the land was partly occupied and cultivated by people (Figure 2). Basic field visits to the site beforehand would have sufficed to make this clear - not to mention an environmental and social impact assessment required by the sub-decree on economic land concession (Royal Government of Cambodia, 2005) and the expropriation law (Royal Government of Cambodia, 2010). However, neither of these took place. The actual use of the land by local peasants was simply disregarded by the concessionaire, who declared during a discussion in 2009 with one of our respondents: 'there is no-one on this land, this is a jungle of tigers and elephants'. Six months after the land deal was struck, a provincial working group was assigned to survey the area (Provincial Administration of Battambang, 2009). The report highlights the impacts the concession would have on people and their land, but does not specify the names of the people concerned, or the exact area affected. It has thus remained of little use in protecting peasants' land rights.

However, the company is not fully active in all of the concession areas: the updated aerial photographs reveal that the area where the company is currently working constitutes approximately 400 ha out of the 5,200 ha allocated. According to our field respondents, the company has been primarily active in deforesting the area and in exporting the resulting timber to Battambang. Our respondents indicated that a local police chief, well known for his involvement in rosewood logging, was partnering the company in clearing the land. Further questions and concerns might also be raised by the fact that running a rubber plantation requires specific skills and knowledge - that the company does not necessarily have - and that it is a labour intensive activity. The deep resentment of the local population towards this concession has hindered the company in hiring local wage labour. In addition, the implementation has required that the area be demined, and this, too, has slowed the process of actually planting rubber trees. The absence of any possibility of poverty alleviation - that might have been an outcome of the provision of local wage-labour - is thus clear, and supports the argument made by Tania Li (2011) that large-scale land acquisition is unlikely to be directed to, or effective in, helping the poor.

Our investigation suggested that the incomplete nature of agricultural operation on the economic concession land had exerted an impact on the local people that was spatially differentiated. In Chhak Rokar and Chamkar Chek (to the north), the mobilization of the people that arose when the company started to establish boundary markers sparked a protest that was locally organized behind a charismatic leader. This resulted in an oral agreement with the company that the people would be allowed to continue cultivating the land they had inside the concession, but that they would not be allowed to encroach further. But people have little trust in the company's assurances, and the future remains uncertain to them. As the company is not currently active in the area, the situation for the farmers is fundamentally business-as-usual. Of importance, however, has been the encouragement from local authorities for farmers to plant as many trees as they can in 
the area under cultivation (including inside the Rath Sambath rubber concession) to ensure that their territory is well marked if the company decides to start operations that are more widespread.

Key contradictions are emerging between central and local state representatives in relation to an acceptance of this concession. These were echoed by a commune council representative: 'They [upper level state authorities] say that we [the farmers] are encroaching on state land, I hear this all the time now. They always put the blame on us. But I want to ask who they think we are? Aren't we the people of this land? Aren't we the state people?'

The establishment of the concession has had tangible effects on people in Ou Ta Teak, where it has resulted in physical eviction and encroachment on a large piece of land that had been the reserve of peasants. These events sparked a profound revolt. The people's request was to allocate a 250 meter-wide strip of land in the area to be available to them as a reserve. Our respondent said that their request was categorically rejected by the company who argued that 'if the land is not cultivated, it does not belong to anyone but us'.

The clearing of the land and the implementation of the rubber plantation was conducted by representatives from the military, who had been hired locally. The threat of violence had been used to intimidate people and, given the asymmetry of power in place, people had no choice but to drop their claim on these lands. This had forced a movement back to the old village locations (Figure 2).

\section{The Variable Geography of Land Titling}

In 2012, a land titling campaign - a nationwide initiative - was implemented in the area by a group of students (wearing military uniforms) and cadastral officers. In Samlaut, general implementation guidelines were taught to the team during a few days of training. The primary focus of the campaign in Samlaut was to title cultivated land in economic or forest concessions that was primarily in conflict zones, or in areas designated for forest rehabilitation (this was reported by a respondent from the district cadastral office). But in view of time and resource constraints, the decision was made to focus primarily on agricultural land adjacent to road corridors (this information was given by a respondent from the district hall). For apparently the same reasons, the team did not work in one single commune of the district (Samlaut commune). Titling took place in Chamkar Chek (Sung commune) but not in Chhak Rokar (Samlaut commune) although they share similar agro-ecological conditions and development problems.

During the implementation of the titling initiative, there was a disparity in the application of the rules across different areas; the results on the ground were contingent on a number of factors. The difference in skills meant that some teams were able to map and demarcate much more land than others, thus leaving a relatively smaller area untitled. Another aspect that resulted in disparities revolved around the capacity and willingness of the titling team to understand the actual history of land occupation of the plot in order to differentiate between a real forest and a fallow area with just a few years of regrowth. Also, the anticipation of the land needs of the next generation was a concern for some students, but not for all. During the titling process, staff working for the Rath Sambath rubber concession were active in moving around, directing the students as to where they should and should not focus their efforts. We also heard reports of illicit land acquisition, usually involving outsiders who had managed (with the help of locals) to clear a piece of land and build a house - literally overnight - in order to take advantage of the cheap titling services on offer and to assert land rights.

Thus, although this titling process aimed to provide security to people whose land ownership was in dispute, we suggest that it has principally reinforced the position of the concession in the area. First, titling has mostly take place outside the concession area and a very limited proportion of land inside was actually titled (Figure 2). Second, only the land under cultivation was titled even if people had a larger claim on the land that was not currently being cultivated. The section of the plot inside the concession that did not receive any title was de facto reassigned as state land which has strengthened the legitimacy of the concession to claim it even if rubber trees have not yet been planted on it. 


\section{FRAGMENTED TERRITORIES AND PEASANTS’ LAND TENURE (IN)SECURITY}

In this section, we examine how these new patterns of territorial fragmentation affect the land security and the perception of it by the peasants.

\section{Ambivalent Attitude Towards Land Titling}

Land possession rights that farmers have enjoyed since the land distribution and appropriation that followed the KR reintegration are based on local forms of bonds between the farmers and the local authority. The compliance with local norms and rules regarding the allocation of land works to legitimize the authorities who are charged with implementing them. Land tenure security is actually constitutive of this social order, of the underlying power networks, and of the relational control over land use exercised by the authorities jointly with the other farmers. The titling brings central state actors - through the multi-level national cadastral administration - into the daily affairs of the village and creates new forms of accountability between the farmers and the authorities that challenge the pre-existing forms of social control over land and land rights in the Constitution and the 2001 land law. This shift is particularly problematic as the titling is a compulsory process that requires additional transaction costs for people in the process of acquiring the title. This was reported to us as an issue that was widespread.

In areas within Samlaut where the land security of people is not significantly challenged, titling is not well received because of the significant land security people have enjoyed locally in the context of local postwar land sovereignties. The absence of clear motivation for people to acquire a title, given the fact that payment of unofficial transaction costs is compulsory, means that people tend to reject the new land right formalization processes. This mistrust was articulated by one of our respondents who is a village representative: '... but now we know how the titling goes and we know what we need to give to actually get the title, so next time they come, we will tell them: "no thank you, we don't need your titling"'.

People reject titling because it is associated with a distant and corrupt administration that is perceived not to be working for the common interest. People actually do not reject the title as a form of security but they do challenge the institutional and political context in which this titling is conducted.

However, in situations where there is more conflict, such as the one around the Rath Sambath rubber concession in Ou Ta Teak village, the process of titling is better accepted and the title is considered as an administrative document that can contribute to land security. However, people consider it as supplemental in that it comes on top of a recognition by local authorities that already exists. This common view was clearly voiced by a village chief who told us: 'I was asked by the higher level [province, district cadastral administration] to collect all titles and make them available to the company so they could see clearly where their land was excised. But I discussed this with my people in the village and we all agreed not to give them the titles because we are afraid they will sell our land. So I just act as if I am deaf.'

This attitude reveals the ambivalent attitude of people towards titles: they accept and welcome the document as a legal proof of possession but reject the institutions that allocate the title to them. In a wider perspective, this ambivalence to titling reflects a tension between the central and local state that is historically rooted in the Northwest region of Cambodia. Rungswasdisab (1995) argued that, since the eighteenth century, Northwestern territories have become a refuge zone for political dissidents opposed to Phnom Penh power. Diepart and Dupuis (2014) have also argued that the fragmentation of state authority has persisted until today between ex-KR local land sovereigns and the neo-liberal state.

\section{Perceptions of Land Tenure Security in a Fragmented Territorial Mosaic}

The process resulting from the overlap of incomplete enclosures and land appropriation by the peasants creates a spatially-explicit mosaic of land fragments (Figure 2). During the interviews, the participants 
produced this mosaic on a map in order to facilitate a discussion about the perception of peasants in respect of land (in)security. Particularly revealing was the fact that these distinct fragments - which were, on the surface, confusing - made a lot of sense to our respondents; they were able to navigate conceptually and articulate very well their perceptions about the risks and uncertainties within each of the fragments (Figure $3)$.

A first observation is that peasants' perceptions of land tenure security do not constitute an absolute judgement. It is rather a relative notion resulting from a comparative calculus between different land fragments. For instance, those who have land outside the rubber concession in Chhak Rokar evaluate their security according to their fellows in Chamkar Chek where titling took place, i.e. the security they have lost by not having their land titled (2). Another important aspect is that people continue to refer to the village chief to assess their land security, even if the land is, on the one hand, titled, or, on the other, particularly at risk (4) (5)). A third key observation is that titles improve the perception of security, but the feeling of insecurity remains significant, even in respect of land located outside the concession (1), (3) and (6). Titling has addressed a limited number of cases where insecurity prevailed, but in a wider perspective it has exacerbated a feeling of tenure insecurity and uncertainty. First, the titling and the land dynamics revolving around the rubber concession have stimulated the development of wealth-biased land markets and the manoeuvres of entrepreneurs and investors from inside and outside the community. The fear of losing additional land in the future is clearly perceptible. Second, the titling was targeted to areas adjacent to the main road where pioneer migrants first became established. The titling has actually consolidated their land assets at the expense of peasant families who are more peripheral, spatially and socially. Third, the process of titling, presented as a tool against land grabs, has reduced the discussion about land security between private ownership and state control over land. This has undermined the legitimacy of past efforts by some members of the communities to promote a common property regime.

In this context of uncertainty and institutional pluralism, the perception of land security, held by peasants, derives from two legitimizing processes of land control: the cadastre anchored in the law, and the local land sovereignty. But a discussion that polarizes the two forms of legitimacy on land control is actually misleading because peasants are not in a dichotomy. They do not gain security either from the land title or from the local authority. They rather navigate between both worlds and by so doing they create new and hybrid forms of land tenure security. What lies at the core of perceptions of land security is the actual trust in the relations established between the peasants and the institutions that provide them with a recognition of their land rights. In such a fragmented and transformative environment the perception of land security is highly contingent on local rules and is thus highly variable and dynamic. 
Figure 3. Respondents' appreciation of land security status resulting from titling and economic land concessions. Note: the numbers included in this figure refer to fragments of territory identified in figure 2

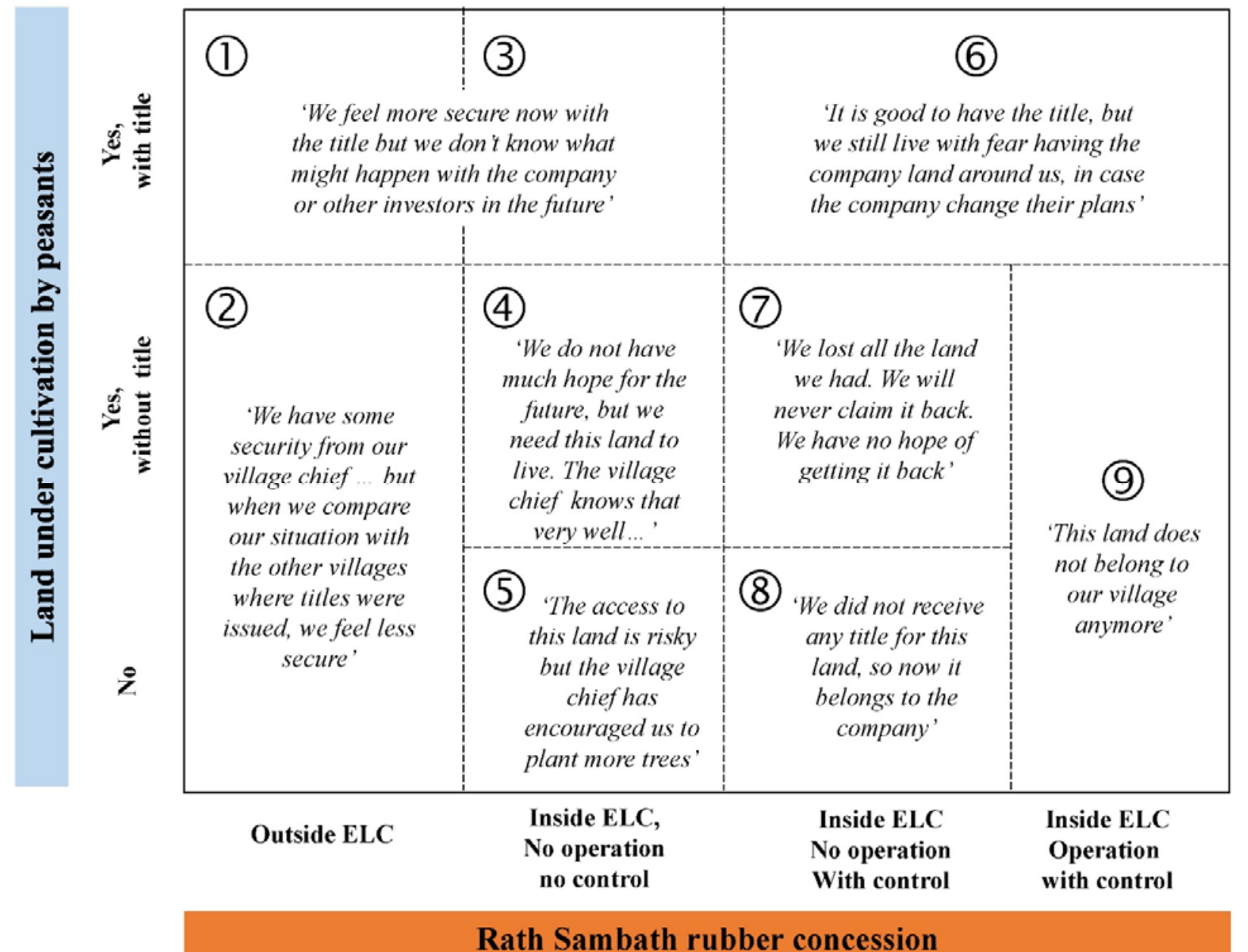

\section{FRAGMENTED TERRITORIES AND SOCIAL DIFFERENTIATION OF THE PEASANTRY}

We now turn to an exploration of how the new forms of land security emerging from the territorial fragmentation affect the pre-existing patterns of social differentiation among the peasantry and whether they indicate new patterns of agrarian change.

\section{Land Tenure Uncertainty and Agrarian Development in Chhak Rokar and Chamkar Chek}

In the early eighties, the first phase of forest pioneering led to the formation of mostly self-subsistenceoriented annual cropping systems. At the end of the nineties, these systems became increasingly commercialized. The main cropping succession is corn (early rainy season) followed by soybean. Corn was extensively cultivated in the early years as the pioneer crop using practices that have negatively affected the chemical and physical properties of the soil (Belfield, Martin, and Scott, 2013). After 6-7 years of continued cultivation, the yield of annual crops decreases sharply and peasants have to compensate through the use of chemical fertilizers to maintain yields. A consequence of this is a decline in their gross margin. This adds to the problems imposed by uncertain weather patterns which render yield and returns unpredictable. 
Except for rice, all annual crops are destined for the market. Products are sold entirely to middlemen working in commodity chains piloted by agro-industrial groups (e.g. CP from Thailand) and entrepreneurs. All the peasants we met told us: 'The market is on the middleman's lips', indicating that they have no power to negotiate with the commercial intermediaries. To engage in this input-demanding agriculture (seeds, fertilizers, pesticides, etc.), farmers are obliged to take short-term credit from different banks, and from formal or informal micro-credit institutions working in the district, and from family or wealthy neighbours. Access to credit is not problematic but is expensive (up to 5 per cent per month for short-term credit). In the context of these highly commercialized and risky agricultural activities, most peasants are trapped in a cycle of debt and reimbursement.

Besides land preparation, all agricultural operations are carried out manually by family labour but also with external labour recruited either as cash-paid casual wage labour (5 USD/day) or within labour exchange groups. Because the demand for agricultural wage-labour is high across the district, the mobility of labour is significant. A central element in labour management is the growing importance of cross-border job migration through which Cambodian workers seize wage labour opportunities in Thailand (5 to 12 USD/day). Job-migration has become part and parcel of labour allocation decision-making, particularly to compensate for crop failure.

In this environment, peasants are trying constantly to secure a viable income portfolio. To address the declining profitability of annual cash crops (corn/soya bean), some are turning to cassava - a crop more resistant to climate irregularities. However, not all farmers can afford this shift as the upfront costs per hectare are more significant for cassava than they are for corn - 590 and 426 USD/ha, respectively, according to our survey in 2014. In addition, cassava is a 10-12 month crop so farmers need the capacity to buffer the absence of cash return during this long period before harvest. In 2004, some farmers started to transform their annual cropping systems into perennial crop systems that can be ranked into three investment/profitability classes (high value: pepper and rubber; medium value: fruit trees such as longan and durian; and low value: cashew). These crops generate a much higher profit (15.300 USD/ha/year for a 10-year production period in the case of pepper), but they remain largely unaffordable for farmers as they require considerable upfront cash investment (e.g. pepper requires an investment of 10,027 USD/ha for the first 3 years of cultivation) as well as the capacity to buffer an absence of income for several years. The capacity of peasants to move from annual to small-scale perennial crop plantation is arguably a key factor in crystalizing the economic differentiation process in this region of Samlaut.

In this context, a marked and rapid social and economic differentiation process has unfolded which is driven by three key factors which are internal to the peasant population: the type of land access which depends on the period of migration (i.e., when the migrants came, or returned, to the region); the availability of a labour force to engage in forest clearing and expansion of agricultural landholdings; and the availability of capital or savings to fund the conversion of an annual crop into small-scale perennial crop plantation (Figure 4).

The earlier migrants, who were usually close to local authority members, received proportionally more land than later migrants, the soil was of better quality and it was located in the village area (thereafter called the centre), outside of the present-day Rath Sambath rubber concession. These advantages were exacerbated as they were also allocated rice land in the lowland plain of Samlaut as part of the post-war land deals. 
Figure 4. Processes of social differentiation between peasants in Chhak Rokar and Chamkar Chek. Note: The numbers refer to the groups of households in Chhak Rokar and Chamkar Chek discussed in the text

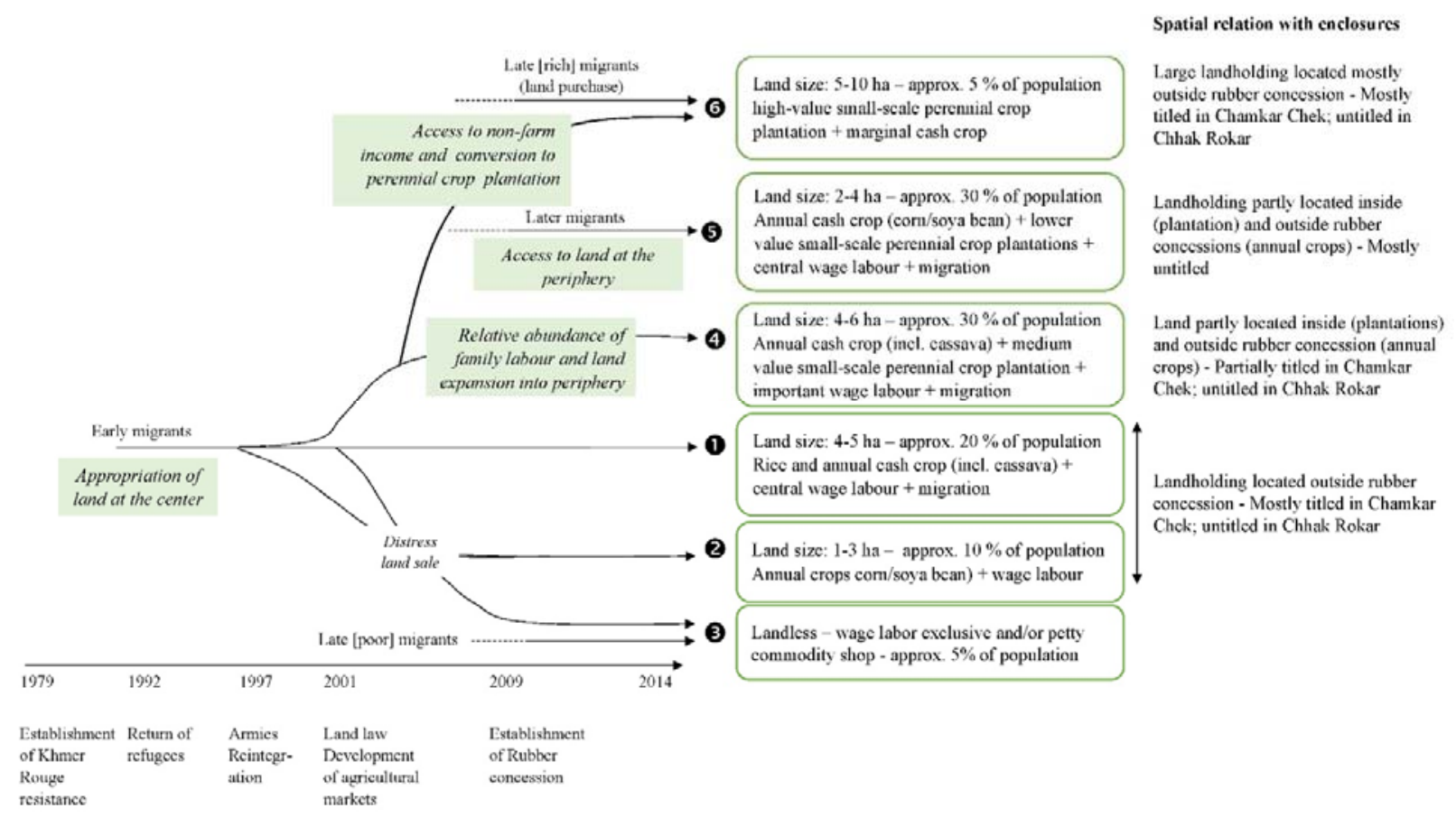

As such, the early phase of the land appropriation was a land rent capture process playing in favour of the early migrants who were KR soldiers and people who had lived there before the war. Among early migrants, those with limited labour capacity have not extended their landholding into peripheral areas and have maintained an annual crop in the centre with a mix of corn/soya beans and cassava cropping systems (group 1, approximately 20 per cent of the population). Given the decline in productivity and profitability of annual crops, they are dependent on wage labour and job-migration. Some landholdings of these early migrants have decreased through distress sales (usually related to health issues); the reliance of these people on off-farm work and job migration is even more pronounced (group 2, approximately 10 per cent of the population). The very late migrants, who could not purchase land, rely exclusively on wage labour and migration to make their living (group 3, approximately 5 per cent of the population). The early migrants with a relative abundance of labour have been able to expand their landholding into more peripheral areas to establish medium-value (mostly fruit trees) perennial crop plantations and possibly engage in cassava production (group 4, approximately 30 per cent of population). Later migrants, dependent on land purchase but with limited financial capacity, have been able to access land only in peripheral areas where they engage in a mix of annual crops and low value perennial plantations (cashew) (group 5, approximately 30 per cent of the population). Those among the early migrants or the new rich migrants with access to savings or non-farm income have been able to pursue the conversion of annual cash crops or to upgrade their existing fruit tree plantations into high value perennial crop plantations such as rubber or pepper (group 6 approximately 5 per cent of the population).

As the processes of differentiation have unfolded along the opening of the agricultural frontier, they have developed a significant spatial expression. We use this association to discuss the impact the enclosures have had on peasants' decision-making processes as they relate to agricultural production and labour allocation.

The peasants of group 6, the better-off, are sheltered from land exclusion and insecurity as their landholdings are located mostly outside the rubber concession. However, all of the peasants in groups 4 and 5 said that the prevailing uncertainty in terms of land tenure had restrained them from upgrading their 
cropping systems to higher value perennial crop plantations; the investment had become too risky for them without financial security. While their landholding size started, or will decrease through inheritance, these families will become more dependent on wage labour and job migration, including cross-border displacement to Thailand. This process is clearly perceptible. However, both enclosures have little effect on the other groups $(1,2,3)$ as their landholdings are located mostly outside the company concession area. However, their dependence on wage labour and job-migration is reinforced as land atomization proceeds through land markets and also through inheritance.

In summary, land uncertainty that has emerged from the territorial fragmentation, influences - not determines - the pre-existing processes of social differentiation between peasants. It has blocked the upward mobility for a majority of peasants and has reinforced the necessity of moving away from the village through wage labour and job-migration.

\section{Land Exclusion and Agrarian Development in Ou Ta Teak}

The agro-ecological context of Ou Ta Teak is strikingly different. The land is of much poorer quality (more shallow, sandy and drought prone) and the landholding per household is much smaller. The land located around the village is used for rice cultivation and as orchard, mostly for self-subsistence. On the hill, the swidden system consists typically of one plot (0.75-1 ha) under cultivation for 1 to 2 years and then left fallow for 4 to 5 consecutive years. Swidden plots are located at a distance that varies from 20 minutes to 4 hours walk from the village. Swidden land produces rice with some corn for feeding livestock. Food insecurity is a major issue. Although commercialization is limited, access to credit is important to enable people to invest in livestock and for survival during lean periods. Labour mobility is prevalent as people migrate to seek wage labour in the district and in Thailand. Given the narrow base of agricultural production, wage labour has a relatively greater importance in the peasant income portfolio in this region.

The very early migrants, who were closely related to the local military unit, received land next to farming water sources, close to current village centres. As in the case of Chhak Rokar and Chamkar Chek, these early migrants received paddies in the lowland area of the district which has sheltered them from food insecurity. Likewise, the land rent capture operated by the early migrants has been significant in the differentiation processes (Figure 5).

In the second half of the nineties, two factors put the swidden agriculture system under pressure. The expansion of land for swidden agriculture was challenged by the establishment of the Protected Area - in which swidden agriculture is supposedly forbidden - and was further complicated by the massive presence of unexploded mines. The arrival of subsequent migrants forced the people to reduce the fallow period in their swidden calendar, thus limiting the natural reproduction of fertility which is essential in a swidden agriculture system. The peasants took advantage of land and resources in the village to progressively abandon swidden cultivation and engage in permanent cropping activities. Those with a relative abundance of labour (group 1, approximately 5 per cent of the population) could materialize their claims on the reserved land that had been allocated to them, while others could not (group 2, approximately 10 per cent of the population). The peasants in this latter group are relatively more dependent on wage labour and job-migration, even if these strategies are adopted more as an opportunity to maximize the labour capacity of the family than as a means of survival. 
Figure 5. Processes of social differentiation between peasants in Ou Ta Teak. Note: The numbers refer to the groups of households in $\mathrm{Ou}$ Ta Teak discussed in the text

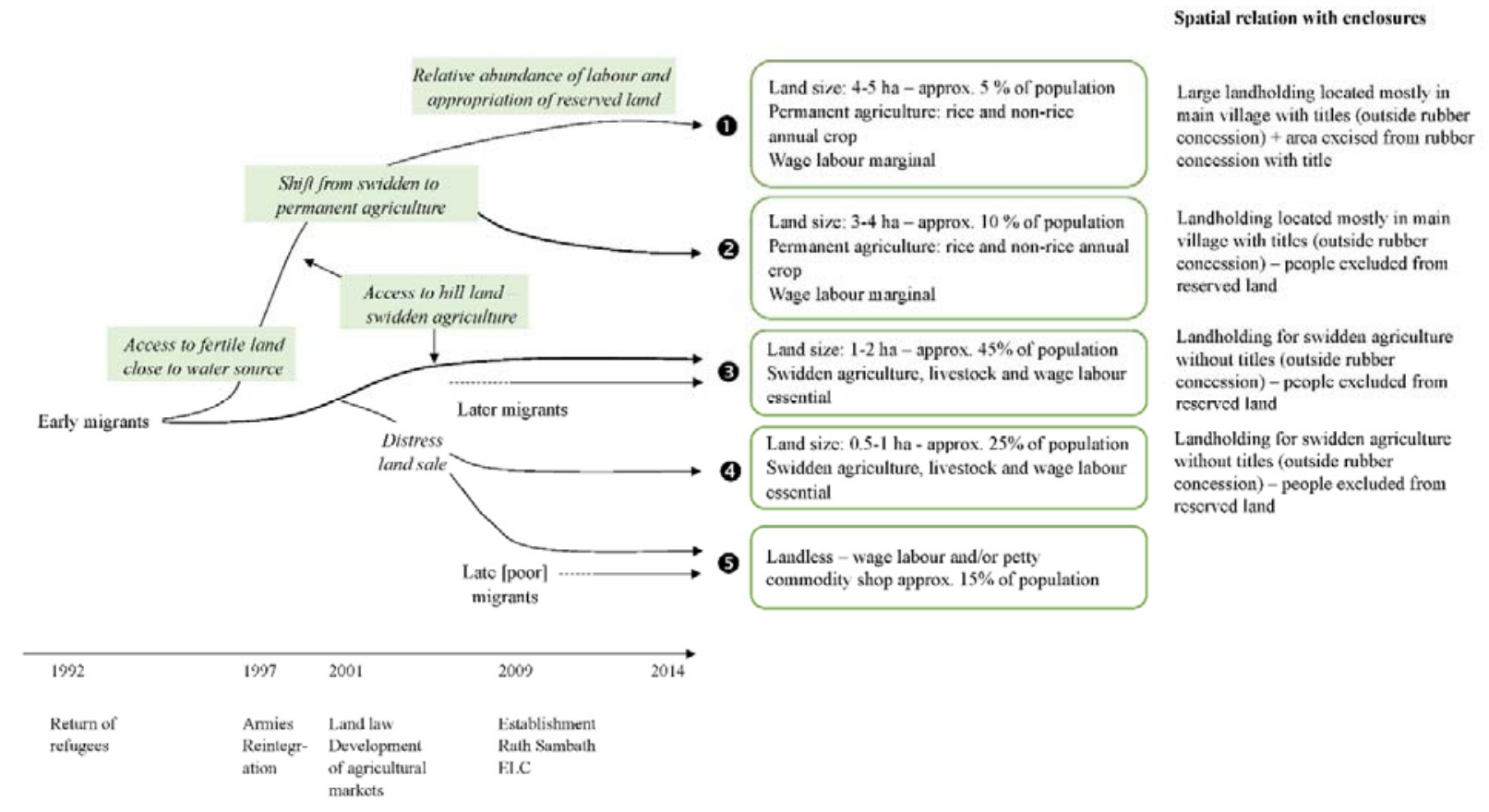

The later migrant households (group 3, approximately 45 per cent of the population) who did not have the necessary connections with local authorities were allocated swidden land, but not land around the village, so their farming options are more limited. The absence of any public services in this new area means that they have little incentive and lack the back-up necessary to cease swidden agriculture and reallocate their efforts to the reserved land. To them, wage labour and job-migration are central elements of their livelihood system. As in other locations, the landholdings of some of these later migrants have decreased through distress sales (related to health issues or to the entrepreneurial pressure of wealthier farmers, officials or newcomers to acquire or enlarge land holdings), thus rendering the dependence on off-farm work and job migration even more acute (group 4, approximately 25 per cent of the population). The very late migrants, who could not purchase land, rely exclusively on wage labour and migration to make their living (group 5, approximately 15 per cent of the population).

As in the case of Chhak Rokar and Chamkar Chek, there is a spatially explicit relationship between the different trajectories of households and the way their landholdings have been affected by the enclosures. The landholdings of group 1 have been largely protected by titling because this group could materialize their claim to the reserved land. This was possible because of privileged access to agricultural land in the village in the early phase of land distribution.

The situation of groups 3 and 4 is significantly different. Their exclusion from land stems from the fact that they have not been able to materialize their claim to reserved land, so they have not received any titles and, as a consequence, have lost all claim rights on this land. These households are now trapped in a very fragile agriculture system and are dependent on the Ministry of Environment official arbitration in respect of their request to extend the area available for swidden agriculture inside the Protected Area. To them, the impact of the enclosure has primarily exacerbated the need to pursue wage labour and job-migration, particularly among the young for whom the land was reserved.

The exclusionary nature of the enclosures is more apparent in Ou Ta Teak than in Chhak Rokar and Chamkar Chek. However, although its influence in respect of the differentiation among peasants is the result of different mechanisms, it nevertheless manifests the same patterns of change. It has given an advantage to those early migrants who were in a favourable position during the land distribution and were able to 
materialize their claim to land inside the present-day rubber concession. For a majority of households who did not have that chance, the enclosures are reinforcing a reliance on wage labour and job migration that was already significant in the village. The enclosures have thus further marginalized those who were more vulnerable.

\section{CONCLUSION: TERRITORIAL FRAGMENTATION AND AGRARIAN CHANGE}

In Cambodia, the interactions between large-scale land investment and land titling - perceived as enclosures - gathered particular momentum in 2012-2013 when the government initiated an unprecedented upland land titling program called Order 01 . This constituted an attempt to address land tenure insecurity in a context where large-scale land investment overlapped with land appropriated by peasants. This article has reviewed how the intersections between both types of enclosure interact with locally embedded land tenure systems to produce new forms of fragmentation in the territories that re-shape pre-existing land-based social relations and dynamics of agrarian systems. The villages studied here represents an area where land titling has intersected with rubber concessions established in 2009 in the Samlaut district - a former Khmer Rouge resistance stronghold in Northwest Cambodia.

In this context, we have conceived the fragmentation of those territories as a result of multi-layered processes of territorialization that bring in central and local state authorities, the population and the various generations of migrants. Central state interventions are embedded in landscapes where post-conflict land distribution to demobilized soldiers and in-migrant peasants was mostly determined by KR warlords. Alongside the agricultural pioneering progression, the emerging social order has crystalized on processes of land control exercised by these KR warlords. Central state territorialization efforts through land concessions and titling are incomplete across space and time due to the speculative nature of the large-scale investments and short-term political motivation of the titling process.

These multi-layered processes of territorialization have resulted in a plurality of institutional arrangements and legitimacies over land tenure security: one exercised by the central state through the cadastral administration and the current exercise of the law, and the second by local state authorities through social consensus and the recognition of actual land appropriation and use. But a contradiction lies at the core of this institutional pluralism: large-scale land concessions and titling, used by the central state to regain control over peripheral regions where it has been historically weak, have actually threatened the legitimacy of the local state that has gained and exercised control through land distribution and recognition of peasant land rights. So, eventually, this conflict has reinforced antagonism between central and local state authorities over territorial control.

These interventions have not only introduced new forms of inclusion and exclusion in land access, but also, and above all, they have induced a widespread perception of insecurity and uncertainty about land rights. This uncertainty is based on the fact that both types of enclosure are incomplete in their implementation. It is also a result of the dynamic of land commoditization, which has stimulated the development of wealth-biased land markets and the related manoeuvres of entrepreneurs and investors active in the surrounding area.

We suggest, however, that peasants are not in a dichotomy "customary versus statutory” land rights and have internalized these contradictions in very pragmatic ways. They do not rely either on formal or informal arrangements, but rather navigate between both worlds and, in so doing, they create new and hybrid forms of land tenure security. The perception of land tenure security is obviously situated in a system with objective economic, social and institutional constraints. But it is also produced through the trust engendered in the relations established between the peasants and the institutions that recognize their rights. This is highly contingent on how local consensus interacts with central state rules. The hybrid nature of these new land tenure arrangements is expressed in the ambivalent attitude of peasants towards titling: while they accept and welcome the title as a legal proof of possession, at the same time they mistrust and reject the institutions that 
allocate the title to them. The result of this process is that titling serves to strengthen the local-level land authority.

The institutional pluralism and the ways peasants have addressed it have reinforced the pre-existing patterns of social differentiation between peasants that crystallized in the capacity of some peasants to control the transformation of annual cropping systems into small-scale perennial crop plantations or in the capacity to control the movement out of swidden agriculture. In all cases, these social differentiation patterns are driven by land control, either through capture of land rent by early migrants in the eighties or through land purchase by some new rich migrants. The inclusion into land formalization processes has benefited those who were already in an upward social mobility trajectory. In contrast, land exclusion and growing uncertainty of tenure have blocked the upward mobility of those who are more vulnerable and who are already dependent on wage labour and job-migration.

Down the line, current transformations exacerbate labour mobility through an increased compulsion for the semi-proletarian peasants to seek wage labour and to pursue job-related migration including crossborder to Thailand. And the institutionalization of off-farm labour tends to reinforce the land control by the local elite.

This movement away from land, associated with the search for wage labour and job-migration, and which results from land exclusion and uncertainty about land tenure, can be seen as an expression of peasant household's agency in responding to rural poverty. We argue that this movement forms the basis on which we can describe future agrarian development in this area. Labour mobility and migration in particular seem driven largely by land formalization processes, and, in a wider perspective, by agrarian dynamics. But perhaps equally important are questions relating to the role that this migration plays in terms of land tenure arrangements and agrarian dynamics. We suggest that future research questions should be framed around this dialectic interrogation.

\section{REFERENCES}

Akram-Lodhi, H. A., 2005. 'Vietnam's Agriculture: Processes of Rich Peasant Accumulation and Mechanisms of Social Differentiation'. Journal of Agrarian Change, 5(1): 73-116.

Akram-Lodhi, H. A., 2007. 'Land, Markets and Neoliberal Enclosure: an agrarian political economy perspective'. Third World Quarterly, 28(8): 1437-1456.

Beban, A., and Work, C., 2016 - forthcoming. 'Mapping the Srok: The Violent Mimeses of Land Title in Cambodia'. Sojourn: Journal of Social Issues in Southeast Asia, 31(1).

Belfield, S. C., Martin, R. J., and Scott, F. J., 2013. 'Alternative Cropping Systems for North-West Cambodia'. International Journal of Environmental and Rural Development, 4(1): 209-214.

Bernstein, H., 2010. Class Dynamics of Agrarian Change. Canada: Fernwood Publishing.

Biddulph, R., 2010. Geographies of Evasion: The Development Industry and Property Rights Interventions in Early 21st Century Cambodia. PhD, University of Gothenburg, Göteborg.

Borras, S., and Franco, J., 2011. Political Dynamics of Land-grabbing in Southeast Asia: Understanding Europe's Role. Amsterdam: Transnational Institute.

Borras, S., and Franco, J., 2012. 'Global Land Grabbing and Trajectories of Agrarian Change: A Preliminary Analysis'. Journal of Agrarian Change, 12(1): 34-59.

Castree, N., 2003. 'Commodifying what nature?’. Progress in Human Geography, 27(3): 273-297.

Chan, S., Tep, S., and Acharya, S., 2001. 'Land Tenure in Cambodia: a Data Update': CDRI Working Paper Series No19.

Chimhowu, A., and Woodhouse, P., 2006. 'Customary vs Private Property Rights? Dynamics and Trajectories of Vernacular Land Markets in Sub-Saharan Africa'. Journal of Agrarian Change, 6(3): 346-371.

De Schutter, O., 2011. 'How not to think of land grabbing: three critiques of large-scale investment in farmland'. The Journal of Peasant Studies, 38(2): 249-279. 
de Soto, H., 2000. Mystery of Capital. New York: Basic Books.

Deininger, K., 2003. Land Policies for Growth and Poverty Reduction. Oxford: Oxford University Press.

Deininger, K., Byerlee, D., Lindsay, J., Norton, A., Selod, H., and Stickler, M., 2011. Rising Global Interest in Farmland. Can it yield sustainable and equitable benefits? Washington: World Bank.

Diepart, J.-C., 2015. The fragmentation of land tenure systems in Cambodia: peasants and the formalization of land rights. Paris: Technical Committee on "Land Tenure and Development”.

Diepart, J.-C., and Dupuis, D., 2014. 'The peasants in turmoil: Khmer Rouge, state formation and the control of land in northwest Cambodia'. The Journal of Peasant Studies, 41(4): 445-468.

Diepart, J.-C., Pilgrim, J., and Dulioust, J., 2014. 'Migrations'. In Atlas of Cambodia: Maps on SocioEconomic Development and Environment, ed Save Cambodia's Wildlife, 89-96. Phnom Penh: SCW.

Dwyer, M. B., 2015. 'The formalization fix? Land titling, land concessions and the politics of spatial transparency in Cambodia'. The Journal of Peasant Studies, 42(5): 903-928.

Elden, S., 2010. 'Land, terrain, territory'. Progress in Human Geography, 34(6): 799-817.

FAO, 2012. Voluntary Guidelines on the Responsible Governance of Tenure of Land, Fisheries and Forests in the Context of National Food Security. Roma: FAO and Committee on World Food Security.

Gironde, C., Golay, C., Messerli, P., Peeters, A., and Schönweger, O., 2014. 'Large scale land acquisitions in Southeast Asia. Rural transformations between global agendas and people's right to food'. Working Paper. Geneva: Swiss Network for International Studies.

Global Witness, 2007. Cambodia’s Family Trees Illegal logging and the stripping of public assets by Cambodia's elite. Washington: Global Witness.

Gottesman, E., 2003. Cambodia after the Khmer Rouge. Inside the politics of nation building. Chiang Mai: Silkworm.

Grimsditch, M., Kol, L., and Depika, S., 2012. Access to Land Title in Cambodia: A Study of Systematic Land Registration in Three Cambodian Provinces and the Capital. Phnom Penh: NGO Forum on Cambodia.

Grimsditch, M., and Schoenberger, L., 2015. New actions and existing policies. The Implementation and Impacts of Order 01. Phnom Penh: The NGO Forum on Cambodia.

Hall, D., Hirsch, P., and Li, T. M., 2011. Powers of Exclusion: Land Dilemmas in Southeast Asia. Singapore and Manoa: NUS Press and University of Hawaii Press.

Hibou, B., 2004. 'Cambodge: quel modèle concessionaire?’. In Le Royaume Concessionaire. libéralisation économique et violence politique au Cambodge, ed J.-F. Bayart, Paris: Fonds d'Analyse des Sociétés Politiques (FASOPO).

Hirsch, P., 2011. 'Titling against grabbing? Critiques and conundrums around land formalisation in Southeast Asia’. Paper presented at the International Conference on Global Land Grabbing. University of Sussex, Brighton, UK

Im, C. L., 2012. Speech at the 19th Meeting of the Government-Development Partner Coordination Committee. Cambodian Rehabilitation and Development Board (CRDB) - Council for the Development of Cambodia (CDC).

Land Tenure and Development Technical Committee, 2010. Large-scale land appropriations. Analysis of the phenomenon and proposed guidelines for future action. Paris: Ministère des Affaires étrangères et du Développment international (Maedi) and Agence Francaise de Développement (AFD).

Land Tenure and Development Technical Committee, 2015. Formalising land rights in developing countries. Moving from past controversies to future strategies. Paris: Ministère des Affaires étrangères et du Développment international (Maedi) and Agence Francaise de Développement (AFD).

Le Billon, P., 2000. 'The Political Ecology of Transition in Cambodia 1989-1999: War, Peace and Forest Exploitation'. Development and Change, 31: 785-805.

Li, T. M., 2011. 'Centering labor in the land grab debate'. The Journal of Peasant Studies, 38(2): 281-298. 
LICADHO, 2014. The Great Cambodian Giveaway: Visualizing Land Concessions over Time Retrieved 13.05.2014, from http://www.licadho-cambodia.org/concession_timelapse/

MAFF, 2009. Request to Prime Minister Hun Sen to review and approve draft Sub-decree on the conversion of permanent forest estate and attribution of economic land concession on 5,200 ha to company Rath Sambath in Battambang - 08 January 2009. Phnom Penh.

Merry, S. E., 1988. 'Legal Pluralism’. Law and Society Review, 22(5): 869-896.

Milne, S., 2013. 'Under the Leopard's Skin: Land Commodification and the Dilemmas of Indigenous Communal Title in Upland Cambodia'. Asia Pacific Viewpoint, 5: 323-339.

Milne, S., 2015. 'Cambodia's Unofficial Regime of Extraction: Illicit Logging in the Shadow of Transnational Governance and Investment’. Critical Asian Studies, 47(2): 200-228.

Müller, F.-V., and Zülsdorf, G., 2013. 'Old Policies - New Action: A Surprising Political Initiative to Recognize Human Rights in the Cambodian Land Reform'. Paper presented at the Annual World Bank Conference on Land and Poverty, Washington DC.

Olivier, M., 1954. Le régime domanial et foncier. Phnom Penh: Missions Francaises auprès des Juridictions Judiciaires Khmères.

Open Development Cambodia, 2014. Maps of Cambodia Retrieved 13.05.2014, from http://www.opendevelopmentcambodia.net/

Pel, S., Le Meur, P.-Y., Sam, V., Laing, L., Pel, S., Hay, L., and Im, S., 2008. Land Transactions in Rural Cambodia. A Synthesis of Findings from Research on Appropriation and Derived Rights to Land: Éditions du Gret.

Peluso, N., and Lund, C., 2011. 'New frontiers of land control: Introduction'. The Journal of Peasant Studies, 38(4): 667-681.

Pilgrim, J., Ngin, C., and Diepart , J.-C., 2012. 'Multiple Migrations, Displacements and Land Transfers at Ta Kream in Northwest Cambodia’. In Migration, Rural Livelihoods and Natural Resource Management, eds S. B. Hecht, S. Kandel and A. Morales, 33-56, El Salvador: International Development Research Centre (IDRC) of Canada - Ford Foundation - Fundación PRISMA.

Polanyi, K., 1957. The Great Transformation. The Political and Economic Origins of our Time. Boston: Beacon Press.

Provincial Administration of Battambang, 2009. Report of a field survey on the impact of conversion of permanent forest estate (attributed as forest concession to Yuri Sako company) and attribution of economic land concession on 5,200 ha to company Rath Sambath in Battambang - 23 July 2009. Battambang.

Royal Government of Cambodia, 2005. Sub-decree on Economic Land Concessions (146 ANK/BK). Phnom Penh.

Royal Government of Cambodia, 2009. Sub-Decree on the conversion of permanent forest estate and allocation of economic land concession to private company for agro-industrial development in Battambang (8 ANK/BK). Phnom Penh.

Royal Government of Cambodia, 2010. Law on Expropriation (NS/RKM 010/003).

Royal Government of Cambodia, 2012. Order 01 on the procedure to reinforce and improve effectiveness of economic land concession management.

Rungswasdisab, P., 1995. War and Trade: Siamese Interventions in Cambodia 1767-1851. PhD, University of Wollongong, Wollongong.

Sack, R. D., 1986. Human territoriality: its theory and history. Cambridge: Cambridge University Press.

Sassen, S., 2014. Expulsions. Brutality and Complexity in the Global Economy. Cambridge-London: The Belknap Press of Harvard University Press.

Scott, J. C., 1998. Seeing Like a State. How Certain Schemes to Improve the Human Conditions Have Failed. New Haven and London: Yale University Press. 
Sikor, T., and Lund, C., 2009. 'Access and Property: A Question of Power and Authority'. Development and Change, 40(1): 1-22.

So, S., 2009. Political Economy of Land Registration in Cambodia. PhD, Northern Illinois University, Dekalb.

Sperfeldt, C., Tek, F., and Chia-Lung Tai, B., 2012. 'An Examination of Policies Promoting Large-Scale Investments in Farmland in Cambodia’. Working Paper. Phnom Penh: Cambodian Human Rights Action Committee (CHRAC).

Springer, S., 2013. 'Illegal Evictions? Overwriting Possession and Orality with Law's Violence in Cambodia'. Journal of Agrarian Change, 13(4): 520-546.

Un, K., and So, S., 2011. 'Land Rights in Cambodia: How Neopatrimonial Politics Restricts Land Policy Reform’. Pacific Affairs, 84(2): 289-308.

von Benda-Beckmann, F., 2002. 'Who's afraid of legal pluralism?'. Journal of Legal Pluralism, 47: 37-82.

White, B., Borras, S., Hall, R., Scoones, I., and Wolford, W., 2012. 'The new enclosures: critical perspectives on corporate land deals'. The Journal of Peasant Studies, 39(3-4): 619-647.

Wolford, W., Borras, S., Hall, R., Scoones, I., and White, B., 2013. 'Governing Global Land Deals: The Role of the State in the Rush for Land’. Development and Change, 44(2): 189-210. 